\title{
Characteristics of Mesenchymal Stem Cells under Hypoxia
}

\author{
Bruna Amorin $^{1,2}$, Ana Paula Alegretti ${ }^{1,2}$, Vanessa de Souza Valim ${ }^{1,2}$, Annelise Martins Pezzi da Silva ${ }^{1,2}$, \\ Maria Aparecida Lima da Silva ${ }^{1,2}$, Felipe Sehn ${ }^{1}$, Lucia Silla ${ }^{1,2}$ \\ ${ }^{1}$ Cell Technology Center, Experimental Research Center, Hospital de Clínicas de Porto Alegre-Porto Alegre, \\ Rio Grande do Sul, Brazil \\ ${ }^{2}$ Graduate Program in Medicine: Medical Sciences, Universidade Federal do Rio Grande do Sul-Porto Alegre, \\ Rio Grande do Sul, Brazil \\ Email: lsilla@hcpa.ufrgs.br
}

Received February 1, 2013; revised March 1, 2013; accepted March 10, 2013

\begin{abstract}
Mesenchymal stem cells (MSC) are considered non-hematopoietic multipotent stem cells with self-renewal properties and the ability to differentiate into a variety of mesenchymal tissues. Optimal conditions for the culture of these cells have been the subject of investigation for several years. In particular, ideal oxygen tension levels have not been established in the literature. In physiological environments, oxygen tension may vary from $12 \%$ in peripheral blood to $1 \%$ in the deep zone of cartilage regions. In any case, oxygen tension is considerably lower in vivo when compared with the normal atmosphere of standard cell culture conditions (21\%). The objective of this study was to review the literature available on MSC characteristics (cell cycle, survival, proliferation, differentiation, morphology, immunophenotype, cytogenetics) when cultured under hypoxic conditions. Our focus on optimal culture conditions is justified by the key role currently played by these cells in regenerative medicine.
\end{abstract}

Keywords: Mesenchymal Stem Cells; Culture; Hypoxia

\section{Introduction}

Mesenchymal stem cells (MSCs), also referred to mesenchymal stromal cells [1], are considered non-hematopoietic multipotent stem cells with self-renewal properties and the ability to differentiate into mesoderm tissues [2]. MSCs were first described by Friedenstein et $a l$. in the 1970s, as cells morphologically similar to fibroblasts and with a high ability to adhere to plastic surfaces [3]. Several subsequent studies have reported the multipotent nature of these cells, i.e., their ability to differentiate into embryonic mesoderm-derived cells, namely, osteocytes, chondroblasts, and adipocytes [4-6].

The first studies designed to assess the effects of different oxygen $\left(\mathrm{O}_{2}\right)$ tension levels in MSC culture date back to 1958, when Cooper et al. and Zwartouw \& Westwood observed that some cells proliferated more rapidly under low $\mathrm{O}_{2}$ tension levels when compared with normal atmospheric levels $[7,8]$.

In recent years, studies have evidenced that MSC are recruited to areas of tissue damage, such as fractures, myocardial infarction, and ischemic brain lesions, where they become involved in both the regulation of inflammatory response and tissue repair [9,10], and hypoxia appears to be an important regulator of MSC recruitment, migration, and differentiation [11,12], In an animal model, Rochefort et al. have shown that MSCs, but not hematopoietic progenitor cells, were mobilized from the bone marrow into peripheral blood through hypoxia [13]. Additionally, low $\mathrm{O}_{2}$ tension levels have been implicated in the maintenance of stem-cell quiescence and plasticity in general [14,15].

Based on the above, studies on optimal in vitro culture conditions have focused on ideal $\mathrm{O}_{2}$ tension levels [16]. In particular, it has been hypothesized that the survival and proliferation of MSCs can be improved by maintaining cells at low $\mathrm{O}_{2}$ tension levels although it remains unclear whether different in vitro concentrations of $\mathrm{O}_{2}$ over long periods of time change typical features of MSC [14]. Within this scenario, a relevant fact is that cultures under standard conditions $\left(21 \% \mathrm{O}_{2}\right)$ are exposed to a significantly higher amount of $\mathrm{O}_{2}$ when compared with physiological in vivo conditions [17]. In fact, approximately $1 \%-1.5 \%$ of the genome appears to be regulated by hypoxia [18].

Recently, with the growing interest in the potential application of MSCs in regenerative medicine, the possibility to obtain a higher rate of proliferation, and the availability of more appropriate methods to change $\mathrm{O}_{2}$ tension levels in culture,has motivated the publication of several studies on the effects of low $\mathrm{O}_{2}$ tension levels on MSC behavior and function [16,17,19,21]. It is important to emphasize that subtle differences in culture con- 
ditions, e.g., medium supplementation with different growth factors, probably account for the heterogeneity of results found in the literature. The present study discusses several described effects of hypoxia on MSC.

\section{Bone Marrow Stromal Cells and MSC Niches}

Stromal cells, together with extracellular matrix and soluble regulatory factors, once regarded as secondary components [22], are currently believed to be essential to maintain hematopoiesis [23]. In addition to MSC, stromal cells, both in vitro and in vivo, are formed by a heterogeneous population of cells including macrophages, fibroblasts, adipocytes, osteoblasts, and endothelial cells. These cells are considered to be the main components of the niche and seem to play a critical role in the regulation of the hematopoietic stem cells [24,25].

The term niche was introduced in 1980 to describe the spatial structure that lodges stem cells [26]. The hematopoietic stem cell niche is located in the bone marrow, and currently there are models that advocate two superimposed populations: the endosteal niche-close to the bone surface, where quiescent hematopoietic stem cells are located and maintained; and the perivascular nicheassociated with sinusoidal endothelial cells, where hematopoietic stem cells primarily divide and self-renew. MSCs are present in these two niches, and they participate in hematopoiesis and ontogeny [23].

\section{MSC Survival in a Hypoxic Environment}

In vivo $\mathrm{O}_{2}$ tension levels have been described to range between $4 \%$ and $7 \%$ in the bone marrow, sometimes reaching as low as $1 \%-2 \%$ [27-30]. Therefore, MSCs and all other stroma cells have to be able to live in a hypoxic microenvironment [31].

MSCs, as all cells, have the ability to effectively change metabolic pathways from aerobic to anaerobic, an essential aspect for the survival of these cells under hypoxic conditions [16]. An experimental study performed with rats on the changes in MSCs under serum-deprivation and hypoxia conditions, concluded that serum deprivation was the main reason leading to ischemiainduced apoptosis of MSCs. However, it also showed that prolonged exposure to hypoxia leaded to mitochondrial dysfunction and Caspase-3 activation, a key factor in apoptosis [32]. Although it has been shown that MSCs are able to withstand hypoxia (e.g., $\mathrm{O}_{2}<1 \%$ ) for at least 48 hours (37), the accumulation of lactate resulting from glycolysis could become an inhibitory factor in the long term [16-33].

When bone marrow-derived MSCs are cultured under hypoxic conditions, intracellular signaling pathways associated with cell survival are stimulated such as hy- poxia-inducible factor- 1 alpha (HIF- $1 \alpha$ ) that when stabilized migrates into the cell nucleus and combines with hypoxia-inducible factor- 1 beta (HIF-1 $\beta$ ). Subsequently, these dimeric structures bind to the promoter region of hypoxia-responsive genes, including glucose-6-phosphate transporter (G6PT), which controls gluconeogenesis. The increased level of glucose resulting from gluconeogenesis appears to contribute to MSC survival under hypoxic or serum-deprivation conditions (37-39). Additionally, an increased survival rate under hypoxia, when compared to normoxia, can be attributed not only to the overexpression of HIF-1, but also to an increase in erythropoietin receptors, and anti-apoptotic factors Bcl-2 and Bcl-XL, followed by decreased Caspase-3 levels (70,71). Moreover, interleukin IL-6 and vascular endothelial growth factor (VEGF)-two proangiogenic factors are also stimulated during hypoxia, further contributing to cell survival (70). These beneficial effects are regulated by a complex array of signaling pathways, including Akt and ERK pathways (26,72,73).

Hypoxia and the HIF- $1 \alpha$ stabilization cause phosphorylation of the Akt signaling pathway which is degraded under normoxia. When Akt is activated, the expression of pro-apoptotic factor Bax reduces, and the expression of anti-apoptotic factor Bcl-2 increases. Such overexpression may interact with the Bax accumulated in the mitochondrion, triggering apoptosis or further stabilization of HIF- $1 \alpha$ causing, as mentioned above, its translocation into the cell nucleus and the activation of hypoxia-responsive genes such as G6PT and angiogenesis-related factors such as VEGF and IL-6 (18).

In addition to $\mathrm{O}_{2}$ tension levels, the optimal culture time of MSCs under hypoxic conditions also remains to be determined. Wang et al. used short time hypoxic preconditioning in MSCs and observed favorable effects on cell viability and angiogenic properties after 10 minutes of culture; stronger effects were observed after longer culture times [34].

\section{MSC Proliferation and Cell Cycle under Hypoxic Conditions}

Despite the fact that physiological levels of $\mathrm{O}_{2}$ tension, even in healthy tissues, are significantly below $21 \%$, cells are most frequently cultured at this $\mathrm{O}_{2}$ tension level. Culture under normal physiological $\mathrm{O}_{2}$ tension levels might affect the proliferation rates of several types of cells [16]. Lenon et al. showed that the culture of MSCs derived from the bone marrow of mice at $5 \% \mathrm{O}_{2}$ resulted in approximately $40 \%$ more cells at first passage when compared with cells cultivated at $21 \% \mathrm{O}_{2}$ [28]. Similar findings were reported for human MSCs by Grayson et $a l$., that showed an increased cell proliferation rate under low $\mathrm{O}_{2}$ conditions (2\%) for 7 passages, resulting in a 30 times higher number of cells when compared with cul- 
tures under normoxia [35]. Hung et al. [20] also observed a higher proliferation capacity of MSCs after 7 days of culture under hypoxia $\left(1 \% \mathrm{O}_{2}\right)$. In the same study, an in vitro migration assay was performed and showed that hypoxia enhanced the migration capacity of MSCs [36]. In spite of a short exposure time (24 hours) at $1.5 \% \mathrm{O}_{2}$, Matin-Rendon et al. also observed increased MSC proliferation [37]. Accordingly, D'Ippolito et al., showed that a low $\mathrm{O}_{2}$ tension level decreased the time necessary for the cell population to double when cultured at $3 \% \mathrm{O}_{2}$ [14], and Ren et al. showed an increase in the number of cells in the G2/S/M phase during hypoxia [38].

Conversely, a study by Holzwarth et al. analyzing MSCs proliferation at $21 \%, 5 \%, 3 \%$, and $1 \% \mathrm{O}_{2}$ observed reduced rates of proliferation after 7 days of culture under hypoxia. In their study, cultures at $21 \% \mathrm{O}_{2}$, considered to be hyperoxic in comparison with the physiological environment in which MSCs reside, showed robust proliferation rates. Assessing MSC cell cycle after 7 days of culture only $1.37 \%$ of the cells entered the $\mathrm{G} 2 / \mathrm{M}$ phase in hypoxic cell cultures $\left(1 \% \mathrm{O}_{2}\right)$ compared with $2.50 \%$ at an $\mathrm{O}_{2}$ concentration of $21 \%$. The authors concluded that the reduced number of cells in the G2/M phase confirms the inhibitory effect on cell proliferation under reduced $\mathrm{O}_{2}$ concentrations [17]. An inhibitory effect on MSC proliferation rate cultured under hypoxia $\left(1 \% \mathrm{O}_{2}\right)$ in a medium containing $17 \%$ of fetal bovine serum (FBS) has also been reported [39].

\section{MSC Plasticity under Hypoxic Conditions}

The multilineage potential of MSCs is one of the reasons underlying their use in regenerative medicine [40]. According to several studies, MSC differentiation into other lineages can either increase or decrease under hypoxia $[17,20,41]$. Some in vitro studies have shown that cultures with low $\mathrm{O}_{2}$ concentrations stimulated differentiation processes, inducing cells to differentiate into adipogenic, osteogenic, or chondrogenic cells [28,38,42]. Conversely, some others have reported suppressive effects of low $\mathrm{O}_{2}$ tension levels on the plasticity of MSCs $[43,44]$.

\subsection{Osteogenic Differentiation}

HIF- $1 \alpha$ and VEGF are MSCs key elements in bone development and regeneration. VEGF is a transcriptional target of HIF- $1 \alpha$ and has an important role in angiogenesis to which osteogenesis-bone development and regeneration, is strongly associated [45].

A study conducted by Huang et al. investigated the effects of hypoxia $\left(5 \% \mathrm{O}_{2}\right)$ in relation to the biological capacity of MSCs obtained from rabbits. That study found that hypoxia significantly increased the proliferation of MSCs, and the expression of messenger RNA
(mRNA) for core binding factor alpha-1 (Cbf $\alpha-1)$ increased 1 hour after hypoxia. These results indicate that hypoxia increases differentiation rates in osteogenic lineages and suggest that $\operatorname{Cbf} \alpha-1$ may be positivity influenced by HIF1- $\alpha$ [41]. Some studies point to an improved osteogenic differentiation capacity of MSCs, however with conflicting results. Lennon et al. cultivated cells for several passages under hypoxia $\left(5 \% \mathrm{O}_{2}\right)$ and also at $21 \% \mathrm{O}_{2}$. Subsequently, the osteogenic differentiation capacity of these cells was assessed, suggesting that $5 \% \mathrm{O}_{2}$ was associated with a better differentiation response [28]. Valorani et al. also observed that, under hypoxic conditions $\left(2 \% \mathrm{O}_{2}\right)$, MSCs obtained from human adipose tissue showed an increase in their potential to differentiate into osteocytes [46]. Another study showed that different rates of $\mathrm{O}_{2}$ (in hypoxia) were associated with different results: cells cultured at $1 \% \mathrm{O}_{2}$ showed a negative effect on osteogenic differentiation, whereas an increase in $\mathrm{O}_{2}$ tension to 3\% caused recovery of osteogenic differentiation [17]. In contrast, D'Ippolito et al. [14], Hung et al. [39], Muller et al. [47], Salim et al. [48], and Martin-Rendon et al. [37] observed either a reduced capacity or no effect on the differentiation capacity of MSCs into osteoblasts under hypoxic conditions or after exposure to hypoxia.

\subsection{Chondrogenic Differentiation}

Although Scherer et al. have shown that $5 \% \mathrm{O}_{2}$ promoted chondrogenic differentiation in the presence of a chondrogenic medium [49] and chondrocytes are known to develop in an extremely hypoxic environment [16] there are few articles assessing hypoxia effects on MSCs chondrogenic differentiation. There are, however, some indirect evidences that hypoxia might play a key role in in vivo MSCs chondrogenic differentiation since Sox9, an important transcription factor involved in chondrogenesis, was observed to be upregulated and to involve HIF- $1 \alpha$ and p38MAPK/Akt pathways under hypoxic conditions, similarly to the MSC survival mechanisms in a hypoxic environment mentioned above [50,51].

\subsection{Adipogenic Differentiation}

Although several studies have suggested that hypoxia can increase the MSCs differentiation in adipocytes [38,42, $46,52,53]$ there are some that suggested hypoxia has no effect [35-54] or even suppress adipogenic MSCs differentiation [39]. Again, several different $\mathrm{O}_{2}$ tension and culture conditions have been utilized in these studies.

\section{MSC Morphology under Hypoxic Conditions}

Some studies have described the morphology of MSCs 
and correlated it with the "quality" of these cells, reporting that smaller cells have higher self-renewal capacity and an enhanced differentiation potential. Grayson et al. observed some differences in cells cultured under hypoxia in terms of their cellular and nuclear morphology, as well as in the formation of reinforced extracellular matrix when compared with MSCs in normoxia [35]. Holzwarth et al. microscopically analyzed the morphology of MSCs cultured under both hypoxic and in normoxic conditions after 1 and 3 weeks of culture. The authors observed that cell morphology under hypoxia was donor-dependent-some samples did not show differences between the two $\mathrm{O}_{2}$ tension conditions, and others died after exposure to hypoxia [17].

\section{Immunophenotypic Characteristics of MSCs under Hypoxic Conditions}

MSC immunophenotype is characterized by the expression of CD73, CD90, CD105, CD106, CD146, and MHC class I molecules, and the absence of markers such as CD45 and CD34 or MHC class II molecules $[1,55]$. According to one study by Holzwarth et al., there were no significant differences in the expression of cell surface markers after 14 days of culture at $1 \%$ when compared to $20 \%$ of $\mathrm{O}_{2}$ [17].

\section{Cytogenetic Characteristics of MSCs under Hypoxic Conditions}

Senescence is a typical phenomenon of the in vitro cells cultures thought to interrupt cell proliferation, and attributed to everal factors, including progressive telomere shortening secondary to loss of telomerase activity [56]. In normal $\mathrm{O}_{2}$ tension, time in culture has been linked to an increase number of mutations and to malignant transformation in murine mesenchymal cells [57] and in human MSC cultures, after more than 50 in vitro passages $[58,59]$. Holzwarth et al. did not see cytogenetic alterations in cultures of MSCs either under hypoxic or normoxic conditions during six weeks of culture [17].

\section{Gene Expression in MSCs Cultured under Hypoxia}

As mentioned above, several studies have described genes that may be under-or over-expressed in MSCs during hypoxia. These genes are involved in different functions, such as DNA repair, cell cycle, chromosome segregation, apoptosis, glycolysis, angiogenesis, proliferation, and adhesion [33,35,60,64]. A study conducted by Onishi $e$ t al. reported over-expression of several genes in rat MSCs cultivated under hypoxia vs. normoxia. That study also revealed that most genes analyzed were upregulated after 24 hours even in cells cultured at $10 \% \mathrm{O}_{2}$ (moderate hypoxia) [64].

The Table 1 describes some of the genes identified in different studies involving human MSCs in relation to their expression during hypoxia.

\section{Immunomodulatory Effects and Homing under Hypoxia}

In addition to the easy isolation and culture of MSCs, their differentiation potential and the associated production of growth factors and cytokines, these cells have also become the focus of attention due to their immunomodulatory properties $[65,66]$. In this context, hypoxia

Table 1. Expression of genes in human MSCs cultured under hypoxic conditions.

\begin{tabular}{|c|c|}
\hline Gene & Function \\
\hline \multicolumn{2}{|l|}{ Upregulated } \\
\hline $\mathrm{HIF}^{\mathrm{a}}$ & Hypoxia-related transcription factor \\
\hline $\mathrm{CXCR}^{\mathrm{bc}}$ & Migration \\
\hline $\mathrm{CX}^{\mathrm{CCR}} 1^{\mathrm{b}}$ & Migration \\
\hline $\mathrm{RRM}^{\mathrm{d}}$ & Ribonucleotide reductase \\
\hline $\mathrm{XRCC}^{\mathrm{d}}$ & DNA repair \\
\hline $\mathrm{KIF} 4^{\mathrm{d}}$ & Chromatid assembly \\
\hline POLQ $^{d}$ & DNA polymerase \\
\hline $\mathrm{E}^{2} \mathrm{~F}^{\mathrm{d}}$ & Cell cycle progression \\
\hline FANCD $^{\mathrm{d}}$ & DNA repair \\
\hline $\operatorname{ESCO} 2^{\mathrm{d}}$ & Sister chromatid cohesion \\
\hline AURKB $^{d}$ & Chromosome segregation \\
\hline CENPN $^{\mathrm{d}}$ & Centromere binding \\
\hline MKI67 ${ }^{\mathrm{d}}$ & Cell proliferation \\
\hline \multicolumn{2}{|c|}{ Downregulated } \\
\hline $\mathrm{TFC}^{\mathrm{d}}$ & Hepatic transcription factor \\
\hline $\operatorname{LEP}^{\mathrm{d}}$ & Metabolism, apoptosis, angiogenesis \\
\hline ANGPT2 $^{\mathrm{d}}$ & Antagonist on vascular remodeling \\
\hline $\mathrm{ZP} 1^{\mathrm{d}}$ & Sperm binding in the pellucid zone \\
\hline$V_{W F}{ }^{d}$ & Platelet binding to endothelium \\
\hline GIMAP4 $^{\mathrm{d}}$ & Development of T cells \\
\hline CD93 $^{\mathrm{d}}$ & $\begin{array}{l}\text { Intercellular adhesion, clearance of } \\
\text { apoptotic cells }\end{array}$ \\
\hline PLVAP $^{d}$ & Cell adhesion \\
\hline ESAM $^{\mathrm{d}}$ & Endothelial cell adhesion \\
\hline PCDH17 ${ }^{\mathrm{d}}$ & Cell-cell connections within the brain \\
\hline
\end{tabular}

References: ${ }^{\mathrm{a} H o l z w a r t h ~ e t ~ a l . ~[17] ; ~}{ }^{\mathrm{b}}$ Hung et al. [39]; ${ }^{\mathrm{c}}$ Liu F., ${ }^{\mathrm{d}}$ Basciano [60]. 
seems to regulate the levels of soluble factors (such as VEGF, fibroblast growth factor-2 [FGF2], hepatocyte growth factor, and insulin-like growth factor 1 [IGF-1]), as well as the levels of tumor necrosis factor alpha (TNF- $\alpha$ ), based on nuclear factor kappa $\beta$-dependent mechanisms [67]. These findings suggest an influence of hypoxia on the immunoregulatory properties of MSCs.

$\mathrm{Wu}$ et al. used human MSCs and observed that most genes were regulated after 24 hours of hypoxia. However, in less than 4 hours of hypoxia, an increased secretion of VEGF and membrane type 1-matrix metalloproteinase (MT1-MMP) was observed, as well as reduced levels of matrix metalloproteinase-2 (MMP2) [68]. Muir et al. also confirmed an increased expression of VEGF under hypoxic conditions [69]. Potier et al. cultivated human MSCs with FBS in hypoxia and observed a decreased expression of TGF- $\beta 3$, as well as increased expression of FGF2 and VEGF after 48 hours. In that study, IL-6, IL-8, and MPC1 levels were not affected [44]. Conversely, in a study by Hung et al., who cultivated MSCs in a FBS-free medium, the expression of IL-6, macrophage chemotactic protein (MCP1) and VEGF was found to be upregulated under hypoxia [39].

In addition to influencing the secretion of soluble factors, hypoxia also regulates chemokine receptors CX3CR1 and CXCR4 [39-70], and hepatocyte growth factor receptor cMet [21]. These receptors increase MSCs' migration and homing potential to cell-damaged areas [16]. Rosova et al. found a possible role of hepatocyte growth factor and its receptor cMet, whose expression is upregulated during hypoxia [21]. One study conducted by Hung et al. showed that hypoxia increased the migration capacity of MSCs [20], whereas Wang et $a l$. showed an improved migration potential of MSCs in brain lesion. In the latter study, the CXCR4 receptor was shown to be involved in ability of these cells to migrate to damaged tissue under hypoxic conditions [70].

Hypoxia has been shown to influence the secretion of trophic factors and membrane markers associated with MSC migration and homing and, in animal models, MSCs cultured under hypoxia appears to have improved immune regulatory performance suggesting a possible role of hypoxia in cellular therapy strategies [71,72]. Migration may involve several cytokines, chemokines, and integrins. Among chemokines, the stromal cell-derived factor-1 (SDF-1/CXCR4 receptor) is expressed in a wide variety of tissues. In this context, SDF-1 is a potent progenitor cell mobilization agent present in the bone marrow niche, and its receptor CXCR4 is essential in the migration and homing of stem cells [73]. Therefore, the interaction between this axis and CXCR4 expression on the surface of MSCs cultured under hypoxia has an important role in the migration of transplanted cells [37].

\section{Final Considerations}

The recent interest in the potential application of MSCs in regenerative medicine and the availability of more appropriate methods for cell cultures were followed by the conduction and publication of several studies assessing the effects of low $\mathrm{O}_{2}$ levels on the behavior and function of MSCs. This condition of cell culture appears to enhance MSCs migration and immune regulatory performance in damaged tissues with relevant consequences for cellular therapy. However, optimal conditions for the culture of MSCs have not yet been clearly defined and it is extremely important to accurately determine whether cells cultured under hypoxia are affected in terms of their differentiation, proliferation, and morphology, among other aspects, including the secretion of trophyc factors and membrane markers associated with MSCs migration and homing. Although the most of studies suggest a beneficial effect of hypoxia on MSCs, some authors have also reported opposite and negative effects. In this context, further research is essential so that a consensus can be reached, especially because of the great interest in standardizing the culture of MSCs for use in cell therapy, a promising tool for the treatment of different malignant conditions that are untreatable today.

\section{Acknowledgements}

The authors are grateful for the financial support provided by Fundo de Incentivo à Pesquisa e Eventos (FIPE/ HCPA).

\section{REFERENCES}

[1] M. Dominici, K. Le Blanc, I. Mueller, I. Slaper-Cortenbach, F. Marini, D. Krause, R. Deans, A. Keating, D. Prockop and E. Horwitz, "Minimal Criteria for Defining Multipotent Mesenchymal Stromal Cells. The International Society for Cellular Therapy Position Statement," Cytotherapy, Vol. 8, No. 4, 2006, pp. 315-317. doi:10.1080/14653240600855905

[2] S. P. Bruder, K. H. Kraus, V. M. Goldberg and S. Kadiyala, "The Effect of Implants Loaded with Autologous Mesenchymal Stem Cells on the Healing of Canine Segmental Bone Defects,” The Journal of Bone Joint Surgery, Vol. 80, No. 7, 1998, pp. 985-996.

[3] A. J. Friedenstein, R. K. Chailakhjan and K. S. Lalykina, "The Development of Fibroblast Colonies in Monolayer Cultures of Guinea-Pig Bone Marrow and Spleen Cells," Cell and Tissue Kinetics, Vol. 3, No. 4, 1970, pp. 393403.

[4] D. J. Prockop, "Marrow Stromal Cells as Stem Cells for Nonhematopoietic Tissues,” Science, Vol. 276, No. 5309, 1997, pp. 71-74. doi:10.1126/science.276.5309.71

[5] A. I. Caplan, “All MSCs Are Pericytes?” Cell Stem Cell, Vol. 3, No. 3, 2008, pp. 229-230. doi:10.1016/j.stem.2008.08.008 
[6] M. F. Pittenger, A. M. Mackay, S. C. Beck, R. K. Jaiswal, R. Douglas, J. D. Mosca, M. A. Moorman, D. W. Simonetti, S. Craig and D. R. Marshak, "Multilineage Potential of Adult Human Mesenchymal Stem Cells,” Science, Vol. 284, No. 5411, 1999, pp. 143-147. doi:10.1126/science.284.5411.143

[7] P. D. Cooper, A. M. Burt and J. N. Wilson, "Critical Effect of Oxygen Tension on Rate of Growth of Animal Cells in Continuous Suspended Culture," Nature, Vol. 182, No. 4648, 1958, pp. 1508-1509. doi:10.1038/1821508b0

[8] H. T. Zwartouw and J. C. Westwood, "Factors Affecting Growth and Glycolysis in Tissue Culture,” British Journal of Experimental Pathology, Vol. 39, No. 5, 1958, pp. 529-539.

[9] S. Aggarwal and M. F. Pittenger, "Human Mesenchymal Stem Cells Modulate Allogeneic Immune Cell Responses,” Blood, Vol. 105, No. 4, 2005, pp. 1815-1822. doi:10.1182/blood-2004-04-1559

[10] C. T. van Velthoven, A. Kavelaars, F. van Bel and C. J. Heijnen, "Mesenchymal Stem Cell Treatment after Neonatal Hypoxic-Ischemic Brain Injury Improves Behavioral Outcome and Induces Neuronal and Oligodendrocyte Regeneration," Brain Behavior Immunity, Vol. 24, No. 3, 2010, pp. 387-393. doi:10.1016/j.bbi.2009.10.017

[11] L. F. Raheja, D. C. Genetos and C. E. Yellowley, "The Effect of Oxygen Tension on the Long-Term Osteogenic Differentiation and MMP/TIMP Expression of Human Mesenchymal Stem Cells," Cells Tissues Organs, Vol. 191, No. 3, 2010, pp. 175-184. doi:10.1159/000235679

[12] L. F. Raheja, D. C. Genetos, A. Wong and C. E. Yellowley, "Hypoxic Regulation of Mesenchymal Stem Cell Migration: The Role of RhoA and HIF-1Alpha," Cell Biology International, Vol. 35, No. 10, 2011, pp. 981-989. doi:10.1042/CBI20100733

[13] G. Y. Rochefort, B. Delorme, A. Lopez, O. Herault, P. Bonnet, P. Charbord, V. Eder and J. Domenech, "Multipotential Mesenchymal Stem Cells Are Mobilized into Peripheral Blood by Hypoxia,” Stem Cells, Vol. 24, No. 10, 2006, pp. 2202-2208. doi:10.1634/stemcells.2006-0164

[14] G. D’Ippolito, S. Diabira, G. A. Howard, B. A. Roos and P. C. Schiller, "Low Oxygen Tension Inhibits Osteogenic Differentiation and Enhances Stemness of Human MIAMI Cells,” Bone, Vol. 39, No. 3, 2006, pp. 513-522. doi:10.1016/j.bone.2006.02.061

[15] L. Liu, Q. Yu, J. Lin, X. Lai, W. Cao, K. Du, Y. Wang, K. Wu, Y. Hu, L. Zhang, H. Xiao, Y. Duan and H. Huang, "Hypoxia-Inducible Factor-1alpha Is Essential for Hypoxia-Induced Mesenchymal Stem Cell Mobilization into the Peripheral Blood,” Stem Cells Development, Vol. 20, No. 11, 2011, pp. 1961-1971. doi:10.1089/scd.2010.0453

[16] R. Das, H. Jahr, G. J. van Osch and E. Farrell, "The Role of Hypoxia in Bone Marrow-Derived Mesenchymal Stem Cells: Considerations for Regenerative Medicine Approaches," Tissue Engineering Part B Reviews, Vol. 16, No. 2, 2010, pp. 159-168. doi:10.1089/ten.teb.2009.0296

[17] C. Holzwarth, M. Vaegler, F. Gieseke, S. M. Pfister, R.
Handgretinger, G. Kerst and I. Muller, "Low Physiologic Oxygen Tensions Reduce Proliferation and Differentiation of Human Multipotent Mesenchymal Stromal Cells," BMC Cell Biology, Vol. 11, 2010, p. 11. doi:10.1186/1471-2121-11-11

[18] R. P. Hill, D. T. Marie-Egyptienne and D. W. Hedley, "Cancer Stem Cells, Hypoxia and Metastasis," Seminars in Radiation Oncology, Vol. 19, No. 2, 2009, pp. 106111.

[19] A. Efimenko, E. Starostina, N. Kalinina and A. Stolzing, "Angiogenic Properties of Aged Adipose Derived Mesenchymal Stem Cells after Hypoxic Conditioning,” Journal of Translational Medicine, Vol. 9, 2011, p. 10. doi:10.1186/1479-5876-9-10

[20] S. P. Hung, J. H. Ho, Y. R. Shih, T. Lo and O. K. Lee, "Hypoxia Promotes Proliferation and Osteogenic Differentiation Potentials of Human Mesenchymal Stem Cells," Journal of Orthopaedic Research, Vol. 30, No. 2, 2012, pp. 260-266. doi:10.1002/jor.21517

[21] I. Rosova, M. Dao, B. Capoccia, D. Link and J. A. Nolta, "Hypoxic Preconditioning Results in Increased Motility and Improved Therapeutic Potential of Human Mesenchymal Stem Cells,” Stem Cells, Vol. 26, No. 8, 2008, pp. 2173-2182. doi:10.1634/stemcells.2007-1104

[22] N. B. Nardi and S. Meirelles Lda, "Mesenchymal StemCells: Isolation, in Vitro Expansion and Characterization," Handbook of Experimental Pharmacology, Vol. 174, 2006, pp. 249-282. doi:10.1007/3-540-31265-X_11

[23] K. Le Blanc and D. Mougiakakos, "Multipotent Mesenchymal Stromal Cells and the Innate Immune System," Nature Reviews Immunology, Vol. 12, No. 5, 2012, pp. 383-396. doi:10.1038/nri3209

[24] C. Lo Celso, J. W. Wu and C. P. Lin, "In Vivo Imaging of Hematopoietic Stem Cells and Their Microenvironment," Journal of Biophotonics, Vol. 2, No. 11, 2009, pp. 619631. doi:10.1002/jbio.200910072

[25] Y. Shen and S. K. Nilsson, "Bone, Microenvironment and Hematopoiesis," Current Opinion in Hematology, Vol. 19, No. 4, 2012, pp. 250-255.

[26] R. Schofield, “The Stem Cell System," Biomedicine Pharmacotherapy, Vol. 37, No. 8, 1983, pp. 375-380.

[27] M. G. Cipolleschi, P. Dello Sbarba and M. Olivotto, “The Role of Hypoxia in the Maintenance of Hematopoietic Stem Cells,” Blood, Vol. 82, No. 7, 1993, pp. 2031-2037.

[28] D. P. Lennon, J. M. Edmison and A. I. Caplan, "Cultivation of Rat Marrow-Derived Mesenchymal Stem Cells in Reduced Oxygen Tension: Effects on in Vitro and in Vivo Osteochondrogenesis,” Journal of Cellular Physiology, Vol. 187, No. 3, 2001, pp. 345-355. doi:10.1002/jcp.1081

[29] T. Ma, W. L. Grayson, M. Frohlich and G. Vunjak-Novakovic, "Hypoxia and Stem Cell-Based Engineering of Mesenchymal Tissues,” Biotechnology Progress, Vol. 25, No. 1, 2009, pp. 32-42. doi:10.1002/btpr.128

[30] Z. Ivanovic, "Hypoxia or in Situ Normoxia: The Stem Cell Paradigm,” Journal of Cellular Physiology, Vol. 219, No. 2, 2009, pp. 271-275. doi:10.1002/jcp.21690

[31] I. G. Winkler, V. Barbier, R. Wadley, A. C. Zannettino, S. Williams and J. P. Levesque, "Positioning of Bone Mar- 
row Hematopoietic and Stromal Cells Relative to Blood Flow in Vivo: Serially Reconstituting Hematopoietic Stem Cells Reside in Distinct Nonperfused Niches,” Blood, Vol. 116, No. 3, 2010, pp. 375-385.

[32] W. Zhu, J. Chen, X. Cong, S. Hu and X. Chen, "Hypoxia and Serum Deprivation-Induced Apoptosis in Mesenchymal Stem Cells," Stem Cells, Vol. 24, No. 2, 2006, pp. 416-425. doi:10.1634/stemcells.2005-0121

[33] S. Lord-Dufour, I. B. Copland, L. C. Levros Jr., M. Post, A. Das, C. Khosla, J. Galipeau, E. Rassart and B. Annabi, "Evidence for Transcriptional Regulation of the Glucose-6-Phosphate Transporter by HIF-1Alpha: Targeting G6PT with Mumbaistatin Analogs in Hypoxic Mesenchymal Stromal Cells,” Stem Cells, Vol. 27, No. 3, 2009, pp. 489-497. doi:10.1634/stemcells.2008-0855

[34] J. A. Wang, T. L. Chen, J. Jiang, H. Shi, C. Gui, R. H. Luo, X. J. Xie, M. X. Xiang and X. Zhang, "Hypoxic Preconditioning Attenuates Hypoxia/Reoxygenation-Induced Apoptosis in Mesenchymal Stem Cells," Acta Pharmacologica Sinica, Vol. 29, No. 1, 2008, pp. 74-82. doi:10.1111/j.1745-7254.2008.00716.x

[35] W. L. Grayson, F. Zhao, B. Bunnell and T. Ma, “Hypoxia Enhances Proliferation and Tissue Formation of Human Mesenchymal Stem Cells," Biochemical and Biophysical Research Communications, Vol. 358, No. 3, 2007, pp. 948-953.

[36] S. P. Hung, J. H. Ho, Y. R. Shih, T. Lo and O. K. Lee, "Hypoxia Promotes Proliferation and Osteogenic Differentiation Potentials of Human Mesenchymal Stem Cells," Journal of Orthopaedic Research, Vol. 30, No. 2, 2012, pp. 260-266. doi:10.1002/jor.21517

[37] E. Martin-Rendon, S. J. Hale, D. Ryan, D. Baban, S. P. Forde, M. Roubelakis, D. Sweeney, M. Moukayed, A. L. Harris, K. Davies and S. M. Watt, "Transcriptional Profiling of Human Cord Blood CD133+ and Cultured Bone Marrow Mesenchymal Stem Cells in Response to Hypoxia,” Stem Cells, Vol. 25, No. 4, 2007, pp. 1003-1012. doi:10.1634/stemcells.2006-0398

[38] H. Ren, Y. Cao, Q. Zhao, J. Li, C. Zhou, L. Liao, M. Jia, H. Cai, Z. C. Han, R. Yang, G. Chen and R. C. Zhao, "Proliferation and Differentiation of Bone Marrow Stromal Cells under Hypoxic Conditions,” Biochemical and Biophysical Research Communications, Vol. 347, No. 1, 2006, pp. 12-21. doi:10.1016/j.bbrc.2006.05.169

[39] S. C. Hung, R. R. Pochampally, S. C. Hsu, C. Sanchez, S. C. Chen, J. Spees and D. J. Prockop, "Short-Term Exposure of Multipotent Stromal Cells to Low Oxygen Increases Their Expression of CX3CR1 and CXCR4 and Their Engraftment in Vivo," PLoS One, Vol. 2, No. 5, 2007, p. e416. doi:10.1371/journal.pone.0000416

[40] D. Baksh, L. Song and R. S. Tuan, "Adult Mesenchymal Stem Cells: Characterization, Differentiation, and Application in Cell and Gene Therapy," Journal of Cellular and Molecular Medicine, Vol. 8, No. 3, 2004, pp. 301316. doi:10.1111/j.1582-4934.2004.tb00320.x

[41] J. Huang, F. Deng, L. Wang, X. R. Xiang, W. W. Zhou, $\mathrm{N}$. Hu and $\mathrm{L}$. $\mathrm{Xu}$, "Hypoxia Induces Osteogenesis-Related Activities and Expression of Core Binding Factor Alpha1 in Mesenchymal Stem Cells,” The Tohoku Journal of Experimental Medicine, Vol. 224, No. 1, 2011, pp.
7-12.

[42] T. Fink, L. Abildtrup, K. Fogd, B. M. Abdallah, M. Kassem, P. Ebbesen and V. Zachar, "Induction of Adipocyte-Like Phenotype in Human Mesenchymal Stem Cells by Hypoxia,” Stem Cells, Vol. 22, No. 7, 2004, pp. 1346-1355. doi:10.1634/stemcells.2004-0038

[43] C. Fehrer, R. Brunauer, G. Laschober, H. Unterluggauer, S. Reitinger, F. Kloss, C. Gully, R. Gassner and G. Lepperdinger, "Reduced Oxygen Tension Attenuates Differentiation Capacity of Human Mesenchymal Stem Cells and Prolongs Their Lifespan,” Aging Cell, Vol. 6, No. 6, 2007, pp. 745-757. doi:10.1111/j.1474-9726.2007.00336.x

[44] E. Potier, E. Ferreira, R. Andriamanalijaona, J. P. Pujol, K. Oudina, D. Logeart-Avramoglou and H. Petite, "Hypoxia Affects Mesenchymal Stromal Cell Osteogenic Differentiation and Angiogenic Factor Expression,” Bone, Vol. 40, No. 4, 2007, pp. 1078-1087.

doi:10.1016/j.bone.2006.11.024

[45] C. Wan, J. Shao, S. R. Gilbert, R. C. Riddle, F. Long, R. S. Johnson, E. Schipani and T. L. Clemens, "Role of HIF1Alpha in Skeletal Development," Annals of New York Academy of Science, Vol. 1192, 2010, pp. 322-326. doi:10.1111/j.1749-6632.2009.05238.x

[46] M. G. Valorani, E. Montelatici, A. Germani, A. Biddle, D. D’Alessandro, R. Strollo, M. P. Patrizi, L. Lazzari, E. Nye, W. R. Otto, P. Pozzilli and M. R. Alison, "Pre-Culturing Human Adipose Tissue Mesenchymal Stem Cells under Hypoxia Increases Their Adipogenic and Osteogenic Differentiation Potentials," Cell Proliferation, Vol. 45, No. 3, 2012, pp. 225-238. doi:10.1111/j.1365-2184.2012.00817.x

[47] I. Muller, M. Vaegler, C. Holzwarth, N. Tzaribatchev, S. M. Pfister, B. Schutt, P. Reize, J. Greil, R. Handgretinger and M. Rudert, "Secretion of Angiogenic Proteins by Human Multipotent Mesenchymal Stromal Cells and Their Clinical Potential in the Treatment of Avascular Osteonecrosis," Leukemia, Vol. 22, No. 11, 2008, pp. 2054-2061. doi:10.1038/leu.2008.217

[48] A. Salim, R. P. Nacamuli, E. F. Morgan, A. J. Giaccia and M. T. Longaker, "Transient Changes in Oxygen Tension Inhibit Osteogenic Differentiation and Runx2 Expression in Osteoblasts," Journal of Biological Chemistry, Vol. 279, No. 38, 2004, pp. 40007-40016. doi:10.1074/jbc.M403715200

[49] K. Scherer, M. Schunke, R. Sellckau, J. Hassenpflug and B. Kurz, "The Influence of Oxygen and Hydrostatic Pressure on Articular Chondrocytes and Adherent Bone Marrow Cells in Vitro," Biorheology, Vol. 41, No. 3-4, 2004, pp. 323-333.

[50] M. Kanichai, D. Ferguson, P. J. Prendergast and V. A. Campbell, "Hypoxia Promotes Chondrogenesis in Rat Mesenchymal Stem Cells: A Role for AKT and Hypoxia-Inducible Factor (HIF)-1Alpha,” Journal of Cellular Physiology, Vol. 216, No. 3, 2008, pp. 708-715. doi:10.1002/jcp.21446

[51] J. C. Robins, N. Akeno, A. Mukherjee, R. R. Dalal, B. J. Aronow, P. Koopman and T. L. Clemens, "Hypoxia Induces Chondrocyte-Specific Gene Expression in Mesen- 
chymal Cells in Association with Transcriptional Activation of Sox9,” Bone, Vol. 37, No. 3, 2005, pp. 313-322. doi:10.1016/j.bone.2005.04.040

[52] W. L. Grayson, F. Zhao, R. Izadpanah, B. Bunnell and T. Ma, "Effects of Hypoxia on Human Mesenchymal Stem Cell Expansion and Plasticity in 3D Constructs,” Journal of Cellular Physiology, Vol. 207, No. 2, 2006, pp. 331339. doi:10.1002/jcp.20571

[53] L. A. Mylotte, A. M. Duffy, M. Murphy, T. O’Brien, A. Samali, F. Barry and E. Szegezdi, "Metabolic Flexibility Permits Mesenchymal Stem Cell Survival in an Ischemic Environment," Stem Cells, Vol. 26, No. 5, 2008, pp. 1325-1336. doi:10.1634/stemcells.2007-1072

[54] S. Carrancio, N. Lopez-Holgado, F. M. Sanchez-Guijo, E. Villaron, V. Barbado, S. Tabera, M. Diez-Campelo, J. Blanco, J. F. San Miguel and M. C. Del Canizo, "Optimization of Mesenchymal Stem Cell Expansion Procedures by Cell Separation and Culture Conditions Modification,” Experimental Hematology, Vol. 36, No. 8, 2008, pp. 1014-1021. doi:10.1016/j.exphem.2008.03.012

[55] E. M. Horwitz, K. Le Blanc, M. Dominici, I. Mueller, I. Slaper-Cortenbach, F. C. Marini, R. J. Deans, D. S. Krause and A. Keating, "Clarification of the Nomenclature for MSC: The International Society for Cellular Therapy Position Statement," Cytotherapy, Vol. 7, No. 5, 2005, pp. 393-395. doi:10.1080/14653240500319234

[56] M. Kassem, M. Kristiansen and B. M. Abdallah, "Mesenchymal Stem Cells: Cell Biology and Potential Use in Therapy,” Basic \& Clinical Pharmacology \& Toxicology, Vol. 95, No. 5, 2004, pp. 209-214. doi:10.1111/j.1742-7843.2004.pto950502.x

[57] M. Miura, Y. Miura, H. M. Padilla-Nash, A. A. Molinolo, B. Fu, V. Patel, B. M. Seo, W. Sonoyama, J. J. Zheng, C. C. Baker, W. Chen, T. Ried and S. Shi, "Accumulated Chromosomal Instability in Murine Bone Marrow Mesenchymal Stem Cells Leads to Malignant Transformation,” Stem Cells, Vol. 24, No. 4, 2006, pp. 1095-1103. doi:10.1634/stemcells.2005-0403

[58] A. S. Grigorian, P. V. Kruglyakov, U. A. Taminkina, O. A. Efimova, A. A. Pendina, A. V. Voskresenskaya, T. V. Kuznetsova and D. G. Polyntsev, "Alterations of Cytological and Karyological Profile of Human Mesenchymal Stem Cells during in Vitro Culturing," Bulletin of Experimental Biology and Medicine, Vol. 150, No. 1, 2010, pp. 125-130. doi:10.1007/s10517-010-1086-X

[59] D. Rubio, J. Garcia-Castro, M. C. Martin, R. de la Fuente, J. C. Cigudosa, A. C. Lloyd and A. Bernad, "Spontaneous Human Adult Stem Cell Transformation," Cancer Research, Vol. 65, No. 8, 2005, pp. 3035-3039.

[60] L. Basciano, C. Nemos, B. Foliguet, N. de Isla, M. de Carvalho, N. Tran and A. Dalloul, "Long Term Culture of Mesenchymal Stem Cells in Hypoxia Promotes a genetic Program Maintaining Their Undifferentiated and Multipotent Status,” BMC Cell Biology, Vol. 12, 2011, p. 12. doi:10.1186/1471-2121-12-12

[61] Y. Jin, T. Kato, M. Furu, A. Nasu, Y. Kajita, H. Mitsui, M. Ueda, T. Aoyama, T. Nakayama, T. Nakamura and J. Toguchida, "Mesenchymal Stem Cells Cultured under Hypoxia Escape from Senescence via Down-Regulation of p16 and Extracellular Signal Regulated Kinase,” Biochemical and Biophysical Research Communications, Vol. 391, No. 3, 2010, pp. 1471-1476. doi:10.1016/j.bbrc.2009.12.096

[62] H. Liu, W. Xue, G. Ge, X. Luo, Y. Li, H. Xiang, X. Ding, P. Tian and X. Tian, "Hypoxic Preconditioning Advances CXCR4 and CXCR7 Expression by Activating HIF1Alpha in MSCs," Biochemical and Biophysical Research Communications, Vol. 401, No. 4, 2010, pp. 509-515. doi:10.1016/j.bbrc.2010.09.076

[63] C. C. Tsai, Y. J. Chen, T. L. Yew, L. L. Chen, J. Y. Wang, C. H. Chiu and S. C. Hung, "Hypoxia Inhibits Senescence and Maintains Mesenchymal Stem Cell Properties through Down-Regulation of E2A-p21 by HIF-TWIST," Blood, Vol. 117, No. 2, 2011, pp. 459-469. doi:10.1182/blood-2010-05-287508

[64] S. Ohnishi, T. Yasuda, S. Kitamura and N. Nagaya, "Effect of Hypoxia on Gene Expression of Bone MarrowDerived Mesenchymal Stem Cells and Mononuclear Cells,” Stem Cells, Vol. 25, No. 5, 2007, pp. 1166-1177. doi:10.1634/stemcells.2006-0347

[65] M. Shi, Z. W. Liu and F. S. Wang, "Immunomodulatory Properties and Therapeutic Application of Mesenchymal Stem Cells," Clinical and Experimental Immunology, Vol. 164, No. 1, 2011, pp. 1-8. doi:10.1111/j.1365-2249.2011.04327.x

[66] C. D. Wan, R. Cheng, H. B. Wang and T. Liu, "Immunomodulatory Effects of Mesenchymal Stem Cells Derived from Adipose Tissues in a Rat Orthotopic Liver Transplantation Model," Hepatobiliary and Pancreatic Diseases International, Vol. 7, No. 1, 2008, pp. 29-33.

[67] P. R. Crisostomo, Y. Wang, T. A. Markel, M. Wang, T. Lahm and D. R. Meldrum, "Human Mesenchymal stem Cells Stimulated by TNF-Alpha, LPS, or Hypoxia Produce Growth Factors by an NF Kappa B, but Not JNKDependent Mechanism," American Journal of Physiology: Cell Physiology, Vol. 294, No. 3, 2008, pp. C675-C682. doi:10.1152/ajpcell.00437.2007

[68] E. H. Wu, H. S. Li, T. Zhao, J. D. Fan, X. Ma, L. Xiong, W. J. Li, L. L. Zhu and M. Fan, "Effect of hypoxia on the gene profile of human bone marrow-derived mesenchymal stem cells,” Acta Physiologica Sinica, Vol. 59, No. 2, 2007, pp. 227-232.

[69] C. Muir, L. W. Chung, D. D. Carson and M. C. FarachCarson, "Hypoxia Increases VEGF-A Production by Prostate Cancer and Bone Marrow Stromal Cells and Initiates Paracrine Activation of Bone Marrow Endothelial Cells," Clinical and Experimental Metastasis, Vol. 23, No. 1, 2006, pp. 75-86. doi:10.1007/s10585-006-9021-2

[70] Y. Wang, Y. Deng and G. Q. Zhou, "SDF-1Alpha/ CXCR4-Mediated Migration of Systemically Transplanted Bone Marrow Stromal Cells towards Ischemic Brain Lesion in a Rat Model,” Brain Research, Vol. 1195, No. 2008, pp. 104-112. doi:10.1016/j.brainres.2007.11.068

[71] X. Hu, S. P. Yu, J. L. Fraser, Z. Lu, M. E. Ogle, J. A. Wang and L. Wei, "Transplantation of Hypoxia-Preconditioned Mesenchymal Stem Cells Improves Infracted Heart Function via Enhanced Survival of Implanted Cells and Angiogenesis," Journal of Thoracic and Cardiovascu- 
lar Surgery, Vol. 135, No. 4, 2008, pp. 799-808. doi:10.1016/j.jtcvs.2007.07.071

[72] X. Mao, Q. Zeng, X. Wang, L. Cao and Z. Bai, “Angiogenic Potency of Bone Marrow Stromal Cells Improved by ex Vivo Hypoxia Prestimulation," Journal of Huazhong University of Science and Technology (Medical Science), Vol. 24, No. 6, 2004, pp. 566-568.

\section{doi:10.1007/BF02911356}

[73] H. Liu, S. Liu, Y. Li, X. Wang, W. Xue, G. Ge and X. Luo, "The Role of SDF-1-CXCR4/CXCR7 Axis in the Therapeutic Effects of Hypoxia-Preconditioned Mesenchymal Stem Cells for Renal Ischemia/Reperfusion Injury,” PLoS One, Vol. 7, No. 4, 2012, p. e34608. doi:10.1371/journal.pone.0034608 